\title{
John Bathurst Thomson MD 1813 - 1850 An Insight into the Times of a Regimental Medical Officer
}

\author{
Maj W Bonnici \\ MRCGP, DCH, RAMC \\ Birdwood Barracks, BFPO 46
}

A memorial to Dr John Bathurst Thomson, Surgeon to the 69th (South Lincolnshire) Regiment, stands on the Upper Barracca Gardens in Valletta, Malta. According to the inscription the monument was "erected to testify the universal affection and esteem" in which the Regiment held its doctor. On the 18th of September 1850, aged 36 years, "He fell a sacrifice to his unshrinking fidelity in the discharge of his duty during the revalence of cholera in Malta".

Whenever I visit this monument I ponder on the events of bygone times and the hardships faced by former Army Medical Officers. What led the officers and men of the 69th to subscribe three days' pay (1) to immortalise their doctor's name? After all, such a fate was not uncommon. Indeed, during the same cholera epidemic, Assistant Surgeon John Caughey Gray, of the 44th (East Essex) Regiment "was most indefatigable in administering to the wants of the poor fellows whose sufferings brought them under his notice", that "he succumbed to the disease, dying a martyr to his professional devotion" (2). Commissioned on the 3rd April 1849, Dr Caughey Gray had been with his Regiment just over a year when he died on the 14th July 1850 , aged 25 years. His was a simple funeral attended only by a "few Officers and private friends, without Military Parade or ostentation" (2).

Dr John Bathurst Thomson was born in Scotland, on the 22nd September 1813. However, his records at Edinburgh University state that he came from Bengal. His elder brother, Lieutenant - Colonel William Thomson, of the 67th Native Infantry Regiment, was Assistant Commissary General in the Presidency of Ferozepore, while his other brother, Thomas, was a Lieutenant in the 9th Native Infantry Regiment of the East India Company. At the time of his death, his sister was residing in India with her elder brother (3). This implies that his family was working for the East India Company and that at some stage Dr Thomson went to Edinburgh to study medicine, taking up residence at 6 Dean Terrace. He graduated from the University of Edinburgh in 1836, obtaining the degree of Doctor of Medicine and the Diploma for Surgery from the College of Surgeons in Edinburgh. He also held the Diploma of Midwifery. His course of training at the Infirmary covered a period of forty eight months.

Medical studies at the University of Edinburgh and at the Royal Infirmary were among the best in Europe. Attendance at lectures was a compulsory prerequisite for admission to the final examination. Dr Thomson attended the lectures given by the then great men of

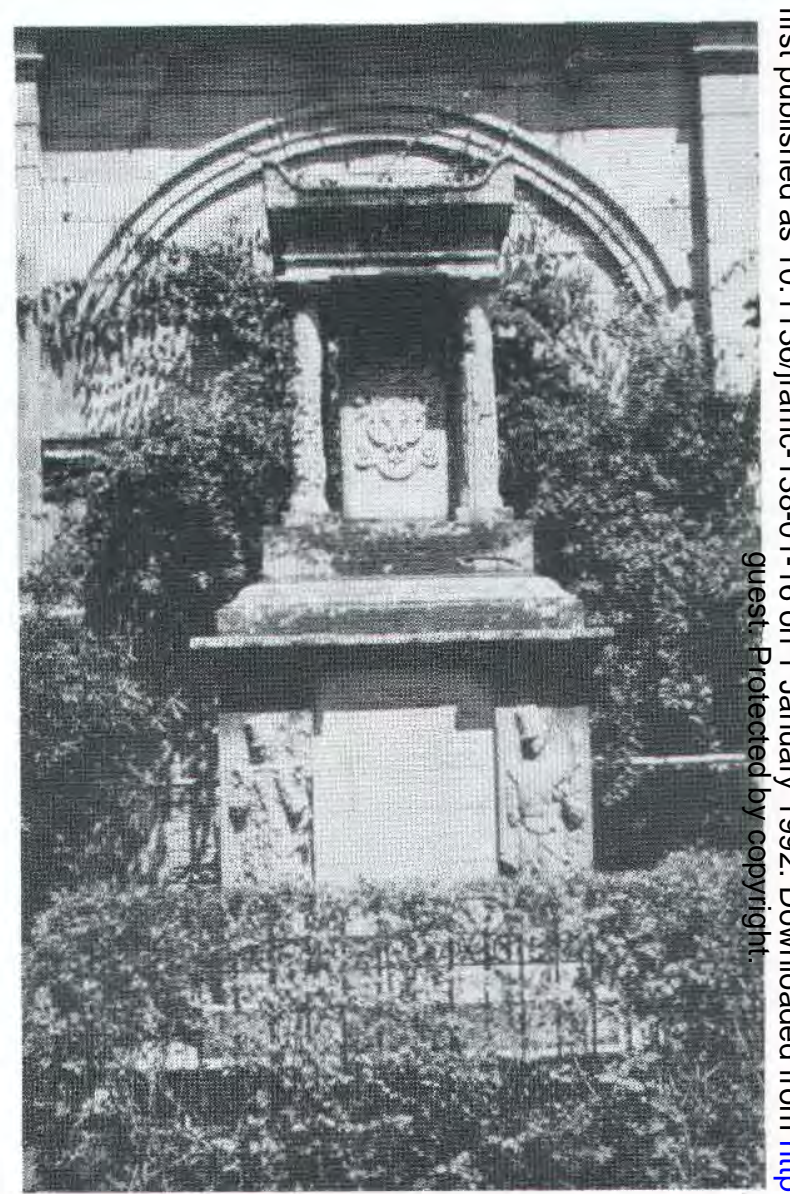

Memorial to Surgeon John Bathurst Thomson Surgeon 69th Regiment

Valletta Malta

Edinburgh. He was tutored by such Professors as: Alexander Monro Tertius, lecturer in Anatomy and the last of the Monro Dynasty who between them held the $\vec{F}$ Chair of Anatomy through three generations; James Syme, the then leading surgeon whose technique for the excision of joints spared the whole limb from amputation; John Thomson, Professor of Pathology and the first to occupy the Chair of Military Surgery when $ᄋ$ this was established in 1807; and Sir Robert Christison, a dominant personality at the Edinburgh Medical School, Professor of Forensic Medicine and later of $\mathbb{N}$ Materia Medica (5). A candidate for the degree of MD was examined in the house of one of the Professors in 
all the branches of medicine. The examination was conducted in Latin. The candidate had to deliver a dissertation on a medical topic, express a written opinion upon the cases of two patients, and discuss an aphorism of Hippocrates. University records show that Dr Thomson's dissertation was entitled "On Misplaced Gout"(6).

On 2nd September 1836, aged 23 years, Dr Thomson applied to join the Medical Department of the Army. This was not an ideal time to apply for a commission, for, after Waterloo, the Army was cut in size and many doctors were relegated to the Half Pay List. It is thus not surprising to find that his application form was annotated: "inform him his name has been entered in the List, but that from the very great number in it, 2 years must elapse before I can offer him prospect of appointment" (4). The Director General of the Army Medical Department, James McGrigor, in "On the Qualifications of Medical Officers in the Army" (1st July 1826), laid down what was expected of applicants. He wrote: "It is desirable that all should have studied Natural Philosophy, Maths and Natural History in all its branches but a liberal education and a competent knowledge of the Greek and Latin languages are indispensable requisites in every candidate" (7). One was eligible for a commission, if unmarried, and aged between 21 and 26 years. He had to have the Diploma of one of the Colleges of Surgeons, and preference was given to those with a university education, and possession of the degree of AM as well as MD. They also had to produce the following testimonials: 18 months' attendance on a hospital where the average number of inpatients was not less than 80; attendance at lectures in anatomy for 24 months; lectures in practical anatomy for 12 months; lectures in surgery for 12 months, or, preferably 6 months surgery and 6 months military surgery; completion of a course of 2 or 3 weekly lectures in clinical surgery, and in physic, spread over 6 months' practice of physic and 6 months of general pathology. They also had to have completed 12 months chemistry; 6 months practical chemistry; 3 months botany; 4 months materia medica; 3 months practical pharmacy or apprenticeship; 5 months natural history, and 4 months midwifery (4).

On 11 January, 1839, Dr J B Thomson was given a commission without purchase, as Staff Assistant Surgeon to the Forces, and sent to Ireland (8). A vacancy arose in the 61st Foot, with the demise of $\mathrm{Dr}$ W Blake on the 27th January. James McGrigor, in his memoranda to the Commander-in-Chief, dated 7 th February, recommended "the appointment of Assistant Surgeon James Smith from the 17th Foot, to be Surgeon vice Blake deceased, and Staff Assistant Surgeon John Bathurst Thomson, to be appointed Surgeon in the 17th Foot vice Smith" (9). Assistant Surgeon J B Thomson was gazetted on 15th February 1839, (10) and joined his Regiment in Bombay (11). The 17th (Leicestershire)
Regiment was one of the four infantry regiment participating in the First Afghan war and Dr $J$ B Thomson was probably present at the assault on the fortress of Ghazni, when on 23 July 1839, the 17th Foof charged the citadel, and at the storming of Khelat on $1 \$$ November (12). After the campaign in Aden of 184 h the Regiment returned to Bombay, from where $D_{0}$ Thomson accompanied them to England, leaving. Bombay on the 14th March, 1847. He was then 3 years and eligible for promotion to Regimentaf Surgeon, having served more than the stipulated five years as Assistant Surgeon. Thus on the 3rd September 1847 Surgeon J B Thomson was transferred to the Reserve Battalion of the 69th (South Lincolnshireq Regiment (13). He joined his new regiment in Englando embarking with them for Malta, and arriving on the island on the 9th December 1847 (11). The First Battalion, the 69th Foot, was quartered at Lower S $\vec{w}$ Elmo Barracks. Its Reserve Battalion was at Cottonera one of the Three Cities across the Grand Harbour. ThP barracks was built during the reign of Grand MasteP Manoel Pinto de Fonesca (1741-73), to store the् ammunition of the Order of St John, and as a safe refuge for females in time of siege. It consisted of these rows of magazines, nineteen on each floor, built wi $i$ the walls under the western wing of the fort. The rof had windows only at one end. The wall opposite moas. formed of the soft porous rock of the bastion itself making the rooms inside damp. Its location below $\$$ high walls of Upper St Elmo hindered free exter ventilation. The Barracks was not a suitable place for housing troops, and was repeatedly condemned. 1856 the ground floor was struck off the troos s? accommodation list and was used as day rooms married quarters (14). The insalubrious lay-out of the Fort was blamed for ill health. It was surmised that "th main cause which predisposed people to cholera wa: want of ventilation in houses arising partly from thei construction, partly from the pernicious habit of whole family sleeping together in one room, and part from unusually cold weather having led people to close all the apertures by which fresh air might have beet admitted, the sleepers being in fact poisoned by the pent up emanations from one another's bodies" (14). The notion that noxious emanations caused disease was now a new concept. In 1750 , John Pringle published monograph on hospital and jail fevers. He argued tha miasma emitted by the many dirty bodies, crowde $F$ together into small windowless rooms, fouls the air, and once inhaled through the breath, the poison cause? malignant or typhus fever. Pringle stressed the need fos the dispersal of patients and for adequate ventilation $s \vec{\Theta}$ that the noxious air could be rendered dilute. This assumption was finally revoked in 1865 , by Louis Pasteur's germ theory of disease.

Asiatic cholera was unknown in Malta, until it firł appeared in 1837 . The second epidemic of 1850 . 
prevailed between the 9th June and 13th October. Out of a Garrison strength of 3,475 , the number of troops contracting cholera was 228 , of whom 135 died, (15) the 44th Regiment bearing the brunt of the epidemic. Cholera first struck Floriana, a suburb of Valletta, where it lingered for some time before spreading to The Three Cities. Among the civilian population in Malta and Gozo of 108,843 there were 4029 cases of cholera with 1,736 deaths (15). The first death was of a merchant Captain who arrived in Malta from Monastir (Tunisia) on the 5th June, and died on Sunday 9th June (16). By the 5th of July, cholera had spread to the 44th Regiment at Floriana, and within a short space 100 were ill, of whom 70 succumbed. The Malta Mail approving the removal of the 44th from the seat of the contagion commented: "The building of the (Civil) hospital appears to have shut out a free circulation of air from the barracks. The immediate vicinity of the burial grounds cannot be the most wholesome, and where 800 to 1000 men may be confined to a narrow spot, and one which is low, it is not surprising when air does not circulate freely that disease should prevail" (17) - yet again reinforcing the then held belief in the theory of spontaneous generation of disease. The encouraging report of the 12th July, that cholera among the troops was diminishing, further supported the value of dispersing the men from "the unhealthy barracks to the airy and wholesome forts Ricasoli and Manoel" (18). The death of Assistant Surgeon J Caughey Gray on the 14th July, necessitated a redistribution of the medical officers. Each battalion had one Surgeon and one Assistant Surgeon and these had to man not only the Regimental Hospitals but also the Forts which sheltered the troops. Thus, Surgeon E Robertson of the 44th moved from the Military Hospital Valletta, to the Military Hospital at Vittoriosa. Assistant Surgeon James Thomson, of the same Regiment was transferred from Fort Manoel to the Military Hospital Valletta, where Assistant Surgeon A S Willocks of the 69th was quartered, and Staff Assistant Surgeon Edward Touch obtained a posting to Fort Manoel (2). Monthly returns for the 1st Battalion 69th Foot, gave an average daily sick of 27 in January 1850, the prevailing disease being "venereal", which increased to an average daily rate of 72 at the height of the cholera (19). By the 16th August cholera among the 44th had virtually ceased but a few deaths were now reported among the troops of the 69 th Regiment (20). Out of 1000 men the 44th Regiment lost 97 or nearly one tenth, besides some 15 women and children. In one ward alone, at the hospital at Isola Gate where there were 18 sick men, the whole in one night were swept off in an incredible short space of time (21) so rapidly did the cholera snatch its victims.

Surgeon John Bathurst Thomson contracted cholera around the 8th September, and died, somewhat unexpectedly, ten days later at the Station Hospital, Valletta. According to his obituary: "In the 69th
Regiment Dr J B Thomson was universally esteemed By his brother Officers he was much beloved, and $b$ the men looked up to with real affection, under the certainty of being kindly treated and properly attendeck to when his services should be required. During th period when the cholera was at its height, hin professional zeal and unwearied exertions to those poo음 fellows who came under his care formed the generat. topic of conversation in almost every circle. To his zeat indeed (for not infrequently he was so occupied that no $\overline{0}^{+}$ bed was pressed by his wearied form for two or threc weeks together) may be firstly attributed the attac which has now terminated fatally. Even when firs smitten he could not be induced to give up hi@ professional pursuits altogether and was finall है removed to a distance from the hospital to the comfortable quarters of Colonel Paxton in command of the Regiment who kindly gave them up to his friend and which he only left two days prior to his decease. His: remains were accompanied to their last resting placE on the afternoon of Wednesday. His body was placed on a gun carriage and preceded by the firing party and two bands, viz The Regimental and Royal Malt.$_{1}^{\circ}$ Fencible Regimental band, was followed by the Mediga? Staff and Officers of his Corps. Then followed the nir of the 69 th Regiment, private friends and serves Officers of the 44th Regiment and of the Garrison, atd private carriages closing the sad procession. So foidd were the men of the deceased that they would not told off as usual for a funeral, thus all the Regiment duty followed, and even the women assisted in the fest token of respect to him whom they had known so longo and esteemed highly. On the corpse reaching the digh between Valletta and Floriana the men insisted removing it from its bier to their shoulders, a stronge? proof of their love for him they could not offer. Thus $\hbar$ D was carried to the tomb the service was solemnla performed by the Garrison Chaplain, and then the thre sad rounds of musketry proclaimed that all was over. $\stackrel{\Omega}{\rightarrow}$ (22).

Dr John Bathurst Thomson lies buried in grave number 205 at the Msida Bastion Cemetery Floriana?. Malta (23). "His death caused a deep gloom to pervadê the Regiment and unequivocal proofs of the esteem which he was held were constantly exhibited". Shortlo afterwards " it was resolved to erect a monument to hi memory; and the Non Commissioned Officers and ment requested to be allowed to take part in the demonstration of esteem by subscribing with hi Colonel and brother Officers at the expense". Before. the monument could be erected the 69th was moved to the West Indies. However, the Reverend $\mathrm{Mr}$ Hare and Mr Julyan of the Commissariat were entrusted with the charge of carrying out the wishes of the many friends of the deceased. The monument was erected in 1851 by: Messrs Darmanin and Sons, reputable sculptors of theifs day. It "fully merits the attention of the visitor as much 
from its intrinsic beauty as a memento to departed worth" (24).

A more fitting tribute to the virtues of Surgeon John Bathurst Thomson would be hard to find. He was indeed worthy of the honour bestowed upon him by the 69th Regiment. Surgeon John Bathurst Thomson epitomized a generation of Army Medical Officers whose unflinching devotion to the care of the sick and wounded in every corner of the empire is a striking example to those who follow in their footsteps.

\section{REFERENCES:}

1. The Times. 30 September $1850: 4 \mathrm{e}$.

2. The Malta Mail and United Service Journal. 19 July 1850. 420.

3. PRO WO 12/7745. Pay List $1850-51,69$ th Foot.

4. PRO WO 25/3927. 1836-37. Qualifications of Candidates for Commissions in the Army Medical Department.

5. Guthrie D. Medical School of Edinburgh. City of Edinburgh Division. The Division 1959.

6. RISSE G B. Royal Infirmary of Edinburgh. Hospital Life in Enlightenment Scotland: care and teaching at the Royal Infirmary of Edinburgh. London. Camb Univ press 1986.

7. PRO WO 30/139. AMD Miscellaneous Correspondence, Papers and Forms 1823-1844. Folio 228. 8. PRO WO 25/199. Commission Notification Book 183
1840 .

9. PRO WO 31/791. Memoranda Papers February 1839.

10. PRO WO $25 / 3219$. Commission Notification Book $183 \overline{8}$ 41.

11. PRO WO 25/3902. Returns of Officers Service: folio 1108.

12. CANTLIE N A. History of The Army Medical Department Vol 1. Edinburgh / London. Churchill Livingstone 1974

13. PRO WO 76/246. Succession of Surgeons 69th Foot.

14. Sutherland J. Report on the Sanitary Conditions of Malta and Gozo with reference to the epidemic cholera 章 the year 1865. London 1867.

15. PISANI S L. Report on the cholera epidemic in the ye 1887. Malta 1888.

16. Malta Times. 11 June 1850. 382.

17. Malta Mail and United Service Journal. 5 July 1850.418

18. Malta Mail and United Service Journal. 12 July 1850 419.

19. PRO WO 17/625. Monthly Returns 69th Foot.

20. Malta Mail and United Service Journal. 16 Aug $185 \mathrm{~g}$ 424.

21. Malta Times. 6 August 1985. 390.

22. Malta Mail and United Service Journal. 20 Sept $185 \overrightarrow{00}$ 429.

23. Zammit C. Survey and Report Msida Bastion Cemegery 1930 Museum Dept Valletta. Malta 1930.

24. The Malta Times. 18 Nov 1851. 457. 